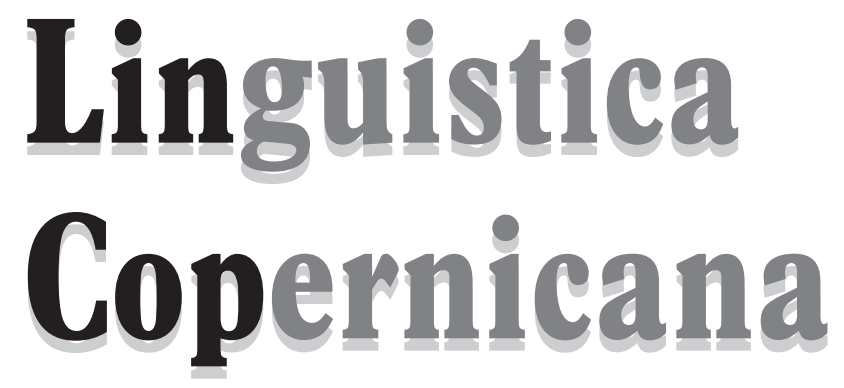

$1(7) / 2012$

WYDAWNICTWO NAUKOWE
UNIWERSytetu MIKOLAJa KOPERNIKA 
REDAKTOR NACZELnY: Maciej Grochowski

Rada Redakcyjna: Ireneusz Bobrowski (Kraków), Andrzej Bogusławski (Warszawa), Gerd Hentschel (Niemcy, Oldenburg), Axel Holvoet (Litwa, Wilno), Krystyna Kleszczowa (Katowice), Roman Laskowski (Kraków), Jarmila Panevová (Czechy, Praha), Jens Nørgård-Sørensen (Dania, Kopenhaga), Zuzanna Topolińska (Macedonia, Skopje), Daniel Weiss (Szwajcaria, Zurich), Anna Wierzbicka (Australia, Canberra)

Kole gi u m R e D K C Y J e: Maciej Grochowski, Krystyna Kallas, Irena Sawicka, Piotr Stalmaszczyk

S E K R ETA R Z R E D A K C I: Iwona Kaproń-Charzyńska

A D R E S R E D A K C J I: Instytut Języka Polskiego UMK, 87-100 Toruń, ul. Fosa Staromiejska 3, e-mail: lincop@umk.pl,www.linguistica.umk.pl

OKŁ A D K A: Monika Pest

(C) Copyright by Wydawnictwo Naukowe Uniwersytetu Mikołaja Kopernika

Toruń 2012

ISSN 2080-1068

Wersją pierwotną (referencyjną) czasopisma jest wersja papierowa.

WYDAWNICTWO NAUKOWE UNIWERSYTETU MIKOEAJA KOPERNIKA

Redakcja: ul. Gagarina 5, 87-100 Toruń

tel. (56) 6114295 , tel./fax 6114705

e-mail: wydawnictwo@umk.pl

Dystrybucja: ul. Reja 25, 87-100 Toruń

tel./fax (56) 61142 38, e-mail: books@umk.pl

www.wydawnictwoumk.pl

Druk: Wydawnictwo Naukowe UMK 


\author{
EMilia Kubicka \\ Uniwersytet Mikołaja Kopernika \\ Instytut Języka Polskiego
}

\title{
O pojęciu GRANICY - raz jeszcze
}

Słow a klucze: granica, początek, koniec, semantyka

Pojęcie tak podstawowe dla ludzkiej percepcji świata jak GRANICA nie mogło nie zostać zauważone zarówno w filozofii, jak i w rozważaniach o języku. Poświęcano mu dłuższe lub krótsze wzmianki, omawiano przy okazji rozważań nad POCZĄTKIEM, KOŃCEM, OGRANICZENIEM, LIMITACJA itp., ale nigdy w sposób ścisły nie zdefiniowano. Podejmując próbę przybliżenia znaczenia rzeczownikowych jednostek opartych na segmencie granica, mam świadomość filozoficznej złożoności problemu, która rzutuje również na używanie tego pojęcia w języku (w tym wypadku we współczesnej polszczyźnie). Przytoczone przeze mnie (w wyborze) poglądy językoznawców i filozofów reprezentują główne punkty w myśleniu o granicy oraz obrazują problemy, jakie łączą się z jej definiowaniem.

* Niniejszy artykuł jest ponowną próbą zmierzenia się z trudnym językowo (i filozoficznie) problemem GRANICY. Pierwszą taką próbę podjęłam w tekście Über den Begriff der Grenze, który ukazał się w XXXIII tomie serii „Die Welt der Slaven” (Kubicka 2008). Opisałam w nim historię percepcji tego pojęcia w filozofii, etymologię wyrażeń granica i Grenze, stosunek pojęcia GRANICY do pojęcia KOŃCA, wyróżniłam dwie jednostki oparte na ciągu granica i zaproponowałam eksplikację jednostki granica czegoś. Na obecnym etapie badań wycofuję się jednak z leżącej wtedy u podstaw eksplikacji propozycji, by granicę czegoś traktować jako część ograniczanego obiektu. 
W początkowej części artykułu będę się posługiwać terminem pojęcie GRANICY z dwóch powodów: po pierwsze, o takich właśnie pojęciach, ideach pisali filozofowie, a o granicy rozumianej tak jak w niniejszej pracy mówili, posługując się również innymi terminami (poczatek, koniec, ograniczenie etc.); po drugie, pisząc o pojęciu, nie przesądzam jego statusu leksykalnego (jednostki leksykalne z ciągiem granica wyróżniam dopiero w punkcie 4), nie istnieje bowiem awalencyjna jednostka o kształcie granica.

\section{Językoznawcy o GRANICY}

Pojęcie to pojawia się w pracach językoznawczych jako niewymagające definiowania, lecz służące do definiowania innych pojęć. I tak GRANICA jest przywoływana obok OGRANICZENIA, KRESU, LIMITACJI, TERMINATYWNOŚCI itp. w literaturze aspektologicznej jako jeden z wyróżników dokonaności (łączonej z KOŃCEM czynności). GranicZność jest według Krystyny Kleszczowej (2005) jedną z „wartości” pojęcia CAŁKOWIToŚci (jeśli możemy o czymś orzec, że jest całkowite, to pośrednio wskazujemy na to, że osiągnęło jakąś granicę). Wciąż powraca pytanie o jej subiektywny bądź obiektywny charakter (por. Cockiewicz 1992: 55-56), związany zresztą z „,subiektywnym”l charakterem ASPEKTU CZY CAŁKOWITOŚCI.

Dłużej nad GRANICĄ zatrzymało się czworo językoznawców. Zacznijmy od punktu granicznego, opisywanego przez Renatę Przybylską i Johna Lyonsa. Przybylska (2006: 78) wyróżniła jego trzy rodzaje: punkt graniczny a) wynikający z natury przedmiotu, b) wyznaczony, explicite wskazany na skali, c) zmienny, językowo niewyodrębniony ${ }^{2}$. Subiektywizm w jej rozumieniu

${ }^{1}$ Problem subiektywizmu w badaniach nad językiem jest obecny od starożytności i pojawia się w wielu dyskusjach nad postrzeganiem świata poprzez język czy punktem widzenia (por. np. Bartmiński 2004a, 2004b). Rozważania na temat subiektywności GRANICY trzeba więc widzieć na tym tle. Nie są one zresztą płodne dla dalszych badań nad nią, gdyż w gruncie rzeczy każde użycie języka, każda wypowiedź są subiektywne: „Bodaj już od czasów Arystotelesa wiadomo bowiem, że stosunek między językiem a stanem rzeczy jest pośredni. Elementem pośredniczącym jest świadomość porządkująca mówiącego. Relacja między tą świadomością (myśleniem o rzeczywistości) a znakiem językowym jest właśnie domeną semantyki języka. [...] Treścią każdej wypowiedzi językowej jest sąd o stanie rzeczy wyrażany przez subiekt czynności mownej, a nie sam stan rzeczy" (Cockiewicz 1992: 12). Zob. również Teubert 2006.

${ }^{2}$ W filozofii w ten sposób o granicy pisał Gottfried Wilhelm Leibniz, który odróżniał GRANICE (Grenze) od ogRANICZENIA (Schranke). Ta pierwsza, odnosząca się do po- 
odsyła do nadawcy jako do członka społeczności językowej, której norm zobowiązany jest przestrzegać:

Teoretycznie nie istnieje żaden graniczny, maksymalny stopień natężenia danej cechy, PD [punkt dojścia - E. K.] nie ma więc swojego stałego, kanonicznego miejsca na skali PW-PD [punkt wyjścia - punkt dojścia - E. K.]. Jego położenie jest identyfikowane bądź jako wyznaczone przez zwyczajową normę dla danego stanu rzeczy, bądź też jest każdorazowo subiektywnie ustalane przez mówiącego (Przybylska 2006: 66).

Niektóre punkty graniczne mogą być przez społeczność wartościowane negatywnie, co pokazuje John Lyons na przykładzie antonimicznych przymiotników typu duży-maty:

Alice Lehrer zauważa, że „,o punktu granicznego lub zerowego zbliża się człon negatywny, a nie człony pozytywne. Rzecz może być tak wąska, tak krótka lub tak mała, że jej rozciągłość jest bliska zeru; natomiast nie ma odpowiedniej granicy tego, jak może być duża, szeroka czy wysoka" [...]. Może dlatego interpretujemy jako ujemne wszystkie leksemy, które funkcjonują składniowo tak jak mały czy waski oraz jak nieuprzejmy i nielegalny (Lyons 1984: 267-268).

Właśnie jako „rodzaj” poczatku/końca GRANICA pojawia się w rozważaniach Adama Bednarka. Autor ten wyróżnia dwie jednostki o kształcie poczatek czegoś (resp. koniec czegoś), mianowicie początek-odcinek ${ }^{3}$ (np. poczatek ksiażki) i początek-punkt. Ta druga odpowiada punktowi granicznemu i jest definiowana następująco:

początek $_{2}$ A: 'to, co jest tą częścią A, przed którą to, co jest, nie jest częścią A

jęć liczalnych, czasoprzestrzennych i wielkości matematycznych, jest stała, niezmienna, podczas gdy druga, służąca do definiowania rzeczy ograniczonych (endliche Dinge), które wciąż dążą do tego, by zmienić swoje ograniczenie (Einschränkung), jest przesuwalna (por. Fulda 1974: 875). Ograniczenie jest zatem dla Leibniza pojęciem myślowym (Verstandesbegriff). Didier Julia (1992: 123) nazywał je limitacją de facto w odróżnieniu od granicy - limitacji de iure. Możliwość wyznaczania granic konwencjonalnych, a więc opartych na ludzkich ocenach, sprawia, że w tej samej kwestii mogą istnieć różne opinie (por. Łukowski 2006: 276).

${ }^{3}$ Por. poczqtek $\mathrm{A}$ : 'ta część A, przed którą to, co jest, nie jest częścią A'; koniec, A: 'ta część A, za którą to, co jest, nie jest częścią A' (Bednarek 1989: 107). 
i o czym myśląc nie można sobie wyobrazić, aby ktoś mógł powiedzieć o czymś innym, iż jest to część tego, o czym myślę’

koniec $_{2}$ A: 'to, co jest tą częścią A, po której to, co jest, nie jest częścią A

i o czym myśląc nie można sobie wyobrazić, aby ktoś mógł powiedzieć o czymś innym, iż jest to część tego, o czym myślę’ (Bednarek 1989: 108)

Według badacza początek-granica jest częścią ograniczanego obiektu, częścią niepodzielną, $\mathrm{w}$ przeciwieństwie do początku-odcinka (Bednarek 1989: 107$)^{4}$.

W rozważaniach Renaty Przybylskiej nad sensem wyznaczania granic powraca Arystotelesowska teza, że ich istnienie jest warunkiem sine qua non istnienia obiektu (por. Cackowski 1989: 176). Granice pomagają człowiekowi w porządkowaniu przestrzeni, wyodrębnianiu obiektów, dlatego wyznacza je nawet tam, gdzie ich nie widzi ${ }^{5}$ :

Pojęcie \#granicy\# może być umotywowane przez dostępne percepcji (wzrokowej, dotykowej itd.) obiektywne cechy przestrzenne postrzeganych bytów (np. przedmioty trójwymiarowe maja \#granicę\#, którą jest powierzchnia, przedmioty wyobrażone jako dwuwymiarowe mają \#granicę\#, którą jest krawędź, brzeg itp.), ale granica bywa też specjalnie konstruowana, wyłącznie wyobrażona i nie mająca ewidentnego korelatu percepcyjnego. [...] Nakładanie konceptualnych \#granic\# na postrzegane otoczenie fizyczne decyduje też na przykład o wyodrębnianiu obiektów relacji przestrzennych, takich jak góry, doliny, pola itp., które same przez się nie mają ściśle fizycznie określonych granic (Przybylska 2002: 108-109).

4 Jako wspólną część stykających się obiektów widział granicę również Arystoteles (por. Fizyka, 227a). Jest to słuszne o tyle, o ile uznanie GRANICY za odrębny byt musiałoby nieuchronnie prowadzić do regresu nieskończonego, gdyż trzeba by wyznaczać granice granic itd. Więcej na ten temat zob. Łukowski 2006: 327.

5 Ta dążność do ,zamykania” obiektów widoczna jest dobrze w metodologii kognitywnej - gdy trudno wskazać granice (ostre), mówi się o granicach rozmytych. Gdy i to nie wystarcza, mowa jest o terytoriach granicznych, strefach przejściowych itd. (por. Kleiber 2003). Łatwiej bowiem percypować świat, gdy pojęcia mają ostre granice - doskonale oddaje to obserwacja Jerzego Pelca: „Nieostrość wyrażenia jest mankamentem jego zakresu. Polega na tym, że nie ma on granicy w postaci linii, np. w postaci okręgu koła, narysowanego dobrze zatemperowanym ołówkiem, lecz zamiast tego - jakby zamazane kontury, szeroki pas ziemi niczyjej, a właściwie nie wiadomo czyjej" (Pelc 1984: 184, za: Łukowski 2006: 307). Do problemu granicy jako linii wrócę w punkcie 2. 
Rodzi się zatem pytanie, czy granice istnieją „,rzeczywiście” czy są tylko konstruktem myślowym, Leibnizowskim Verstandesbegriff, a ich wyznaczanie wynika jedynie z potrzeb społecznych ${ }^{6}$.

Z kolei Leszek Berezowski, translatolog, posługuje się GRANICA jako kryterium decydującym o użyciu rodzajników w językach, które nimi dysponują. Zajmując się nazwami własnymi, których wyznacznikiem formalnym jest między innymi to, że nie wymagają rodzajnika, opisuje on wypadki, w których taki rodzajnik musi się pojawić. Główna teza jego rozważań zamyka się w twierdzeniu, że rodzajnik przy nazwie własnej pojawia się wtedy, kiedy obiekt ją noszący nie ma wyraźnych granic. Ilustrują ją liczne przykłady, z których przytoczę kilka wraz z wyjaśnieniami autora:

a) Montana vs. the West (stan mający granice vs. niezdefiniowany region),

b) Libya vs. the Sahara (państwo mające oficjalne granice vs. pustynia z niezdefiniowanymi granicami, na dodatek wciąż zmieniająca zasięg),

c) Stratford upon Avon vs. the Avon (miasto mające oficjalne granice vs. rzeka, która może się rozlać poza swoje koryto, zmienić bieg lub wyschnąć),

d) Great Britain vs. the English Channel (wyspa ograniczona przez linię brzegową vs. kanał z „otwartym końcem”),

e) Piedmont Avenue vs. the Piedmont (aleja ograniczona przez szerokość jezdni vs. region nie mający oficjalnych granic) (Berezowski 2001: $226-227)^{7}$.

Badacz pojmuje granice państw, regionów, miast i wyodrębnionych przestrzennie obiektów „o stałej konstrukcji” (wysp, ulic) jako oczywiste, nieprzesuwalne, co nie odbiega, zdaje się, od intuicji przeciętnego użytkownika języka, jakkolwiek nie zawsze jest prawdą, bo granice miast czy państw

${ }^{6}$ Pisząc o formowaniu się granic narodowych, socjolog Georg Simmel (1983: 467) ujął to następująco: „Die Grenze ist nicht eine räumliche Tatsache mit soziologischen Wirkungen, sondern eine soziologische Tatsache, die sich räumlich formt" [Granica nie jest faktem przestrzennym, który oddziałuje na socjum, lecz faktem socjologicznym, który kształtuje się przestrzennie]. Tłumaczenia cytatów obcojęzycznych pochodzą od autorki, E. K.

7 Do odrębnej grupy, niezwiązanej już z granicznością, należą przykłady takie, jak Holland vs. the Netherlands, Lyke Eyre vs. the Great Salt Lake, Russia vs. the Soviet Union - rodzajnik w drugim przykładzie każdej pary jest wyznacznikiem proprialności nazwy deskryptywnej, zbyt podobnej do appellativum (por. Berezowski 2001: 229). 
mogą się zmieniać tak samo jak granice rzek czy pustyni, różnica polega na tym, że te pierwsze muszą być określone administracyjnie i nie są widoczne (ich wyznacznikami są słupy graniczne, ogrodzenia, linie na mapie itp.), te drugie natomiast widoczne i dlatego postrzegane jako granice, nawet jeśli działy administracyjne przebiegają gdzie indziej. Przeciętny użytkownik języka abstrahuje na przykład od tego, że granica państwa sąsiadującego ze zbiornikiem wodnym zwykle nie biegnie po linii brzegowej, lecz po dnie tego zbiornika w miejscu oddalonym od miejsca jego styku z lądem itd. Wyjaśnienia badacza traktuję zatem jako nie do końca przekonujące, zwłaszcza kiedy, pisząc, że rodzaj percypowanych granic nie ma znaczenia, wymienia:

borders which are defined by law (e.g. countries, states, shires, national parks, etc.), by natural features of individual referents (e.g. shorelines of lakes and islands, outer walls of castles, abbeys, churches, stadiums, stations, etc.) and in a variety of other ways (e.g. bodies of humans and namable animals, covers of books, endpoints of poems, movies, and performances, frames of pictures, etc. $)^{8}$ (Berezowski 2001: 228).

Tymczasem właśnie ludzie, książki, przestawienia, obrazy, ale także zamki, stadiony czy góry językowo nie mają granic, to znaczy wyrażenia typu *granica Pawła czy *granica zamku malborskiego są nieakceptowalne. Zatem nawet rozważania językoznawców dotyczą raczej pojęcia GRANICY (ujętej filozoficznie), a nie jednostek opartych na kształcie granica. Przechodząc do semantycznego opisu jednostek fundowanych na granicy, chciałabym krótko przedstawić jej obraz leksykograficzny.

\section{Granica w leksykografii}

Porównanie artykułów hasłowych GRANICA we współczesnych słownikach języka polskiego pozwala dostrzec w nich pewne prawidłowości. We wszystkich wyróżniono kilka definicji tego ciągu, ale w tej podanej na pierwszym

${ }^{8}$ Granice, które są definiowane przez prawo (np. krajów, stanów, hrabstw, parków narodowych itp.), przez naturalne cechy indywidualnych referentów (np. linie brzegowe jezior i rzek, zewnętrzne mury zamków, opactw, kościołów, stadionów, stacji itp.) i na wiele innych sposobów (np. granice ludzi i nazwanych zwierząt, okładki książek, końce wierszy, filmów, przedstawień, ramy obrazów itd.). 
miejscu zawsze mówi się o linii oddzielającej jakiś obszar od sąsiednich, por. choćby definicję z SJPD:

'linia zamykająca lub oddzielająca pewien określony obszar; kraniec, kontur, zarys; linia oddzielająca terytorium jednego państwa od innych, uwidoczniona w terenie za pomocą umownych znaków (słupów, kopców)' (GRANICA 1)

Jest ona o tyle charakterystyczna, że mowa w niej o linii, której fizycznie nie ma. Owszem, dziś przeciętnemu użytkownikowi języka nasuwa się skojarzenie z mapami, gdzie granice są właśnie w ten sposób przedstawiane, ale przecież żadne linie w rzeczywistości nie istnieją. Takie niewidoczne działy starano się uwidocznić, robiąc nacięcia na drzewach albo wbijając $\mathrm{w}$ ziemię gałązki czy usypując kopczyki - znaki te nazywano graniami ${ }^{9}$ - po to, by zaznaczyć koniec jednej przestrzeni i początek drugiej (por. SEBor). Od XIII w. granica miała znaczenie 'linia zamykająca lub oddzielająca określony obszar' (SEBor) i to ono zostało zapożyczone do języka niemieckiego (na obszarze władztwa zakonu niemieckiego oznaczało obszar graniczny ['Landmark', por. Hoffmeister 1955: 282]). Dopiero później używano go w innych niż przestrzenne kontekstach, dla XVI w. notuje się znaczenie 'zakres działania lub pojęcia, norma, reguła, prawo' - dziś w SPsł i SEBor opatrzone kwalifikatorem dawne. Słowo granica używane dla oznaczenia początku lub końca bytu nieprzestrzennego innego niż prawo czy norma musiało pojawić się później, bo nie notuja go ani SStp, ani SPXVI ani SESł, ani SEBań, ani SEBor. Dopiero w SW pojawia się definicja: GRANICA 2 przen. 'miara, miarka, kres, koniec, meta, zakres, ramy, kompetencja'.

Drugą cechą wspólną definicji słownikowych jest to, że w definiensie tego ciągu pojawiają się wyrażenia koniec, kres, kraniec (SJPD GRANICA 1 i 2; SWJP GRANICA 1, 3 i 4; USJP GRANICA 2b i 2c), a tylko w ISJP pisze się explicite o poczqtku:

Granica jakiegoś stanu, bytu, pojęcia itp. jest tam, gdzie one się zaczynają, albo tam, gdzie się kończą i przestają być sobą, stając się czymś innym (ISJP GRANICA 5).

9 SEBor: *granb 'ostra krawędź'. O etymologii granicy wyczerpująco pisze S. Kochman 1975: 62-68. Granica jako 'limes’ funkcjonowała według niego pierwotnie u Słowian zachodnich (na wschodzie używano określenia rubież), a różnice znaczeń w poszczególnych językach słowiańskich są dowodem na to, że nie jest ona prasłowem. 
Odpowiada to, jak się zdaje, potocznemu pojmowaniu granicy, która - nawet jeśli jest widziana jako 'ograniczony zasięg, zakres czegoś dozwolonego, przyjętego, możliwego’ (SWJP) - to raczej jako „granica górna” niż „dolna” (zob. 3).

Jakie ,znaczenia” zatem wyróżniają słowniki?

A. W pierwszej kolejności jest to (przedstawiona jako linia) granica terytorialna, najczęściej administracyjna. Ilustracja materiałowa definicji nie jest jednak jednolita. Przytoczę przykłady/kolokacje kolejno z SJPD, ISJP, USJP:

Zmierzch począł zacierać granice między niebem i ziemią. Patrzył na żywą mapę ogromnego obszaru, który rozciągał się w dole aż po sinawą granicę gór. Już granica, polskie chaty, te płaszczyzny, te niziny, co żegnały nas przed laty. Niemiec za zbiegiem rozpuścił modlitwy, więził, mordował aż do granic Litwy. Ćwiczył rycerstwo w sztuce wojennej dla bezpieczeństwa granic.

Mieszkali w pobliżu wschodniej granicy... Przekraczaliśmy granicę o północy... $\mathrm{Na}$ całym świecie wielkie lotniska przenosi się poza granice miast... ...granica Polski z Białorusią... ...granica między Polską a Węgrami... Wewnętrzne granice państw Unii w praktyce przestaną istnieć... Sznury samochodów czekają na granicy polsko-niemieckiej.. Rząd zapewnia, że granica nie zostanie zamknięta.

Granica parceli, wsi, miasta, województwa. Wschodnia, zachodnia granica regionu.

Na pierwszym miejscu wśród granic w SJPD wymienia się nie administracyjne, ale te nieuchwytne, wyznaczane przez mówiącego, dopiero potem mowa jest o granicach państw. Z kolei w ISJP zebrano przykłady odnoszące się wyłącznie do granic administracyjnych. W USJP natomiast wspomina się również o granicach regionów, które nie zawsze są w sposób ścisły wyodrębnione administracyjnie.

B. Granica nieterytorialna jest najczęśniej defniowana jako 'linia podziału, czynniki różnicujące jakieś zjawiska' (SWJP GRANICA 2, por. też ISJP GRANICA 5, USJP GRANICA 2a). Do ilustracji tego znaczenia niech posłużą przykłady z ISJP:

Bohater filmu zmaga się z kłopotami w świecie, gdzie zatarte są granice dobra i zła... Trudno wskazać granicę między poezją podrzędną a wybitną... Reżyser nie przekracza tej niebezpiecznej granicy, poza którą z dramatu robi się kicz. 
Granica przebiega więc między pojęciami abstrakcyjnymi, nie tylko niewyodrębnionymi przestrzennie, ale też subiektywnie pojmowanymi.

C. Trzeci rodzaj granicy wyróżnianej w słownikach opatruje się definicjami typu 'pewien ograniczony zasięg, miara, kres czegoś dozwolonego, przyjętego; koniec, kres możliwości’ (SJPD GRANICA 2; por. też SWJP GRANICA 3 i 4, ISJP GRANICA 6, USJP GRANICA 2b i 2c) i podaje przykłady typu:

Celina zrozumiała, że zwierzenia czynione córkom powinny mieć rozsądne granice... Wiedział dokładnie, czym krytyka zajmować się powinna, gdzie zaś przebiega granica, za którą jest już tylko nadużyciem... ....granice etyki zawodowej (ISJP GRANICA 6).

Dla definicji słownikowych jest charakterystyczne wyznaczanie granic w zależności od tego, do jakiego obiektu się one odnoszą - przestrzennego, jak w punkcie A, czy abstrakcyjnego, jak w punktach B i C. Te dwa ostatnie rodzaje granicy różnią się tym, że jedna jest „linią” podziału między dwoma (explicite nazwanymi) pojęciami, a druga „linią” ograniczającą jeden obiekt.

Punktem wyjścia moich rozważań będzie ustalenie postaci jednostek fundowanych na ciągu granica. W ISJP, który jako jedyny podaje miejsca walencyjne jednostek, wszystkie wyróżnione jednostki mają kształt granica czegoś, ale jest to, zdaje się, uproszczenie (zob. 4). Zanim jednak przystąpię do analizy składniowej i semantycznej tego ciagu, chciałabym się zatrzymać nad stosunkiem GRANICY do KOŃCA (POCZĄTKU).

\section{Granica a koniec (POCZąTek)}

Pokazanie różnicy między tymi pojęciami jest istotne o tyle, o ile często granica jest definiowana właśnie przez koniec $(k r e s)^{10}$. Wydaje się, że granica nie jest nacechowana pod względem początku i końca; jeśli mówimy o granicach czegoś, to nie ma znaczenia, czy to coś się w tym miejscu zaczyna czy kończy, por. np.

10 Por. V księga Metafizyki Arystotelesa. O stosunku GRANICY do POCZĄTKU (KOŃCA) oraz o dystrybucji jednostek górnaldolna granica czegoś pisałam szczegółowiej w artykule Kubicka 2008: 126-128. 
(1) Sznury samochodów czekają na granicy polsko-niemieckiej ${ }^{11}$.

(2) Trudno wskazać granicę między poezją podrzędną a wybitną.

Granica zresztą zawsze implikuje istnienie co najmniej dwóch bytów ograniczanego i sąsiadującego z nim, a koniec (początek) odnosi się tylko do jednego. Końce mają stany (koniec spania), procesy (koniec fermentowania) czy wydarzenia (koniec wystęu), okresy (koniec grudnia) czy byty przestrzenne (koniec kija, koniec drogi) - użycie ciągu granica w tych kontekstach prowadziłoby do dewiacji. Koniec i początek obiektu są dane, łatwe do rozpoznania w rzeczywistości (koniec kija, koniec konferencji), granicę mówiący ustanawia tam, gdzie zarys/zakres obiektu trzeba ustalić, bo nie jest on oczywisty dla wszystkich uczestników komunikacji. Substytucja w odwrotnym kierunku również nie jest możliwa: granice wiedzy to co innego niż koniec wiedzy, granica odnoszona do obiektów terytorialnych w ogóle nie jest substytuowalna przez koniec, por. granice Polski vs. *koniec Polski, granica między niebem i ziemiq vs. *koniec nieba i poczqtek ziemi.

Kolejną różnicę między tymi pojęciami pokazał Adam Bednarek (1989: 106-108): jednostka koniec czegoś (poczatek czegoś) jest dwuznaczna, może odnosić się do odcinka lub do punktu - i tylko ten ostatni może być postrzegany jako granica. Według badacza koniec (początek) jest częścią obiektu, tymczasem status GRANICY jest niejasny, skłaniałabym się raczej do uznania jej za odrębny byt, w pewnym sensie „wspólny” dla sąsiadujących obiektów ${ }^{12}$.

Granica konotująca początek lub koniec pojawia się w ściśle określonych kontekstach - tam, gdzie mowa o granicy dolnej lub górnej (uznaje je za odrębne jednostki języka). Jednak również w tych wypadkach granica i koniec nie są równoważne semantycznie, granica bowiem implikuje obecność otoczenia, innego bytu lub innych bytów, por.:

(3) Dolną granicą tej strefy jest linia śniegu suchego.

(3a) Początkiem tej strefy jest linia śniegu suchego.

11 Przykłady pochodzą ze współczesnych słowników języka polskiego oraz z Narodowego Korpusu Języka Polskiego (www.nkjp.pl). Część z nich została skonstruowana przez autorkę.

12 „Dla Hegla granica jest prymarnie czymś wewnętrznie określonym, co zarówno łączy coś z czymś innym, jak też to coś od czegoś innego oddziela. Ta podwójna funkcja granicy [...] dla pojęcia czegoś ma takie konsekwencje, że coś wskazuje na swój niebyt i jednocześnie w niego przechodzi”, pisze Hans-Friedrich Fulda (1974: 876). 
(4) Ścieżka wznosi się coraz wyżej i mija górną granicę lasu.

(4a) Ścieżka wznosi się coraz wyżej i mija koniec lasu.

Tam, gdzie jest mowa o wartościach wyrażanych liczbowo, wyrażenia koniec czy poczatek $\mathrm{w}$ ogóle nie wystąpią, por.:

(5) Powstanie tzw. korytarz cenowy, czyli dolna i górna granica cen, po których dany producent będzie sprzedawał te same produkty.

(5a) *Powstanie tzw. korytarz cenowy, czyli początek i koniec cen, po których dany producent będzie sprzedawał te same produkty.

\section{Jednostki fundowane na pojęciu GRANICY}

Co zatem ma granice? Kolokacje wyszukane w Narodowym Korpusie Języka Polskiego są następujące (w wyborze):

(6) granica terenu, obszaru, kompleksu, strefy, działki, miasta, województwa, państwa

(7) granica wschodnia, południowa, zachodnia, północna, zewnętrzna; polsko-niemiecka

(8) granica administracyjna, państwowa, historyczna

(9) granica cięcia, zasięgu, odcinka

(10) granica wieku, kary

(11) granica wytrzymałości, możliwości, bezpieczeństwa, ubóstwa

Przykłady zebrane w (6)-(8) odnoszą się do granic terytorialnych, w (9) do granic pojętych ściśle, wręcz terminologicznie, podobnie w (10), gdzie mowa jest o granicy dolnej i górnej, wreszcie w (11) granice wyznaczają zakres pojęć abstrakcyjnych. Poza wielkościami matematycznymi (i w pewnym sensie terytorialnymi) byty, które użytkownik języka „ogranicza”, nie mają granic postrzegalnych zmysłowo, nie muszą nawet być bytami rozciagłymi w czasie lub przestrzeni, por. (11). W języku naturalnym nie mówimy o granicach przedmiotów, istot żywych, czynności (por. *granica stotu, *granica psa, *granica biegania). Granica bowiem jest bytem raczej myślowym niż rzeczywistym - wyobrażamy sobie coś jako zamknięte, odrębne, stawiamy 
granice tam, gdzie w rzeczywistości ich nie ma, o czym piszą badacze zajmujący się tabu:

Zur Unterscheidung von Klassen / Dingen / Aktivitäten werden (non)verbale Symbole verwendet. So werden Grenzen innerhalb eines Bereiches, der von Natur aus kontinuierlich ist, geschaffen. [...] Grenzen trennen soziale Raum-Zeit-Zonen, die für sich normal, zeitlich klar umrissen, zentral und profan sind. Sie sind räumliche und zeitliche Markierungen, ,psychologische Zäsuren” (Malinowski 1973: VI), und betonen die Unterschiede, nicht die Ähnlichkeiten der Katego$\operatorname{rien}^{13}$ (Balle 1990: 23).

Świadczy o tym także etymologia tego słowa, omówiona w punkcie 3. Granica była niewidocznym w sensie fizycznym działem między dwoma bytami, wyznaczanym mniej lub bardziej arbitralnie, w każdym razie nie wypływającym z natury.

Powstaje zatem pytanie, czy granica należy do bytu czy znajduje się między bytami. Z jednej strony bowiem mówi się o granicy czegoś, np. (wschodniej) Polski, możliwości, rzeczywistości, z drugiej o granicy między czymś a czymś, np. między niebem a ziemią (2). Być może zatem mówiący, używając różnych konstrukcji syntaktycznych, mają co innego na myśli. Jeśli mówię o granicach rzeczywistości, to mówię o rzeczywistości. Jeśli zaś mówię o granicy między rzeczywistością a nierzeczywistością, zwracam uwagę na to, że istnieją rzeczywistość i nierzeczywistość i że są one różne. Proponuję zatem uznać istnienie dwóch jednostek opartych na ciągu granica: granica czegoś i granica między czymś a czymś (to rozgraniczenie jest również widoczne w podziale na dwie jednostki czasownikowe oparte na segmencie -granicz-: coś graniczy z czymśs ${ }^{14}$ i coś rozgranicza coś i coś).

13 Do rozróżniania klas / rzeczy / czynności używa się (nie)werbalnych symboli. Granice wyznacza się wewnątrz obszarów, które z natury są ciągłe. [...] Granice dzielą strefy przestrzenno-czasowe, które same w sobie są normalne, wyraźnie określone czasowo, centralne i zwykłe. To przestrzenne i czasowe znaczniki, „cezury psychologiczne” (Malinowski 1973: VI), które podkreślają różnice, a nie podobieństwa kategorii.

14 Jednostce tej słowniki przypisują konsekwentnie dwa znaczenia, z których drugie jest niewątpliwie wtórne, por. ISJP: 1 Jeśli jakieś obszary graniczą ze sobą, to ich terytoria do siebie przylegają. Od południa Polska graniczy z Czechami i Słowacja. 2 Jeśli jakaś sytuacja lub stan graniczy z czymś, to jest prawie tym. Jej szlochanie doprowadziło go, zrównoważonego dotychczas człowieka, do wybuchu graniczqcego prawie z atakiem histerii. 
Idąc dalej tropem związków składniowych, zauważymy, że zwykle nie mówi się o granicy, ale o granicach czegoś, a więc o granicach możliwości, wytrzymałości, obłędu, absurdu, fatszu, głupoty, a nie o granicy możliwości, wytrzymałości itd. Gdy ktoś mówi o granicy głupoty, wskazuje na jedną z jej możliwych limitacji („koniec”, ,początek”), natomiast wyrażenie granice głupoty odsyła do relacji tego bytu względem innych bytów - do „ograniczania" obiektu w sensie filozoficznym (por. Hoffmeister 1955: 282). Taka GRANICA jest w wypowiedzeniu realizowana za pomoca pluralnej formy granice. Jeśli mówimy o granicy czyichś możliwości, granicy wolności słowa, granicy tolerancji ekologicznej, granicy pojemności czy granicy normy (we wszystkich tych przypadkach mówimy też, a może przede wszystkim, o ich granicach), to dlatego, że określamy w ten sposób ich dolną lub górną granicę. O granicy (nie: granicach) bytu mówi się, gdy chce się ją wyznaczyć i gdy jest to w ogóle możliwe, na przykład przez podanie jakiejś zasady, mierzalnej wartości lub przez ostensję - w przypadku granic bytów przestrzennych (dotyczy to również granic miast, państw itp.). Jednocześnie każda granica jest „granicą między”, bo oddziela jeden byt od drugiego.

Rodzaj bytów oddzielanych granicą ma znaczenie dla ilości konstrukcji syntaktycznych, za pomocą których mówi się o tym. Wypływa to jednak z konwencji pozajęzykowych, a nie z właściwości wyrażenia granica. O granicy między państwami można powiedzieć, że jest to:

(12) granica między Polską a Niemcami

granica Polski i Niemiec

granica Polski z Niemcami

granica polsko-niemiecka

W wypadku mniejszych jednostek terytorialnych wybór jest mniejszy, por.:

(13) granica między Warmią a Mazurami / Berlinem a Poczdamem granica Warmii i Mazur ${ }^{15}$ / Berlina i Poczdamu

15 W tym ujęciu Warmia i Mazury zostaną zapewne potraktowane przez użytkownika języka polskiego jako jeden byt, zgodnie z tradycją ujmowania tego terytorium w geografii i historii. Jest to jednak uwarunkowana historycznie incydentalna właściwość, por. jednoznacznie odczytywane wyrażenie granica Kujaw i ziemi chetmińskiej. 


\section{granica Warmii z Mazurami / Berlina z Poczdamem}

*granica warmińsko-mazurska / *berlińsko-poczdamska

Ostatni z zaproponowanych schematów jest używany tylko w odniesieniu do nazw państw. Drugi i trzeci schemat są możliwe, ale rzadkie. Wszystko to, jak zaznaczyłam, jest czysto konwencjonalne. „Granica między”, nawet jeśli na powierzchni wyrażenie między nie występuje, jest pojmowana (umownie) jako linia oddzielająca dwa obiekty, punkt styku między nimi, nie należący jednak do żadnego z nich. O tym, że ,granica między” jest bytem odrębnym, może świadczyć na przykład niedewiacyjność wypowiedzenia:

(14) Wisła w Toruniu stanowi granicę między Kujawami a ziemią chełmińską.

Granica między obiektami częściej jest widziana jako przestrzenna, mówimy o niej, że gdzieś leży, którędyś przebiega. Może mieć swoją nazwę, por.:

(15) Warunki wznowienia stosunków dyplomatycznych z rządem Mikołajczyka: 1) oficjalne oświadczenie rządu polskiego, iż uznaje on linię Curzona za podstawę ,nowej granicy” między ZSRR a Polską [...]

i często jest postrzegana jako rozciągła w przestrzeni, por.

(16) Jest taka jaskinia na pograniczu Słowacji i Węgier, gdzie na środku jaskini stoi krater i to jest granica dokładnie między dwoma państwami.

(17) Drzewa i krzewy stanowią tu naturalne granice między posesjami.,

zwłaszcza jeśli w tej przestrzeni coś się dzieje:

(18) Ja miałem swój paszport pod ręką - jako obywatel kraju drugiej kategorii wciąż byłem kontrolowany na granicach między Europą Wspólną a niewspólną.

(19) Włókna te zagęszczają się na granicy między błoną wewnętrzną a środkową, wytwarzając błonę sprężystą wewnętrzną. 
Językowo traktuje się granicę jako odrębny byt: można ją wyznaczać, przeprowadzać, a także przekraczać lub przesuwać ${ }^{16}$. Granica może mieć swoje właściwości, z jednej strony może być zatarta, nieostra, mglista, plyn$n a$ itd., z drugiej jasna, wyrazista itd.

Granice między obiektami nieprzestrzennymi są reprezentowane przez mniejszą liczbę schematów składniowych, por.:

(20) granica między poezją wybitną a podrzędną

?granica poezji wybitnej i podrzędnej

?granica poezji wybitnej z podrzędną

*granica poezji wybitno-podrzędnej

I znowu wynika to, zdaje się, z konwencji językowych. Ale, podobnie jak w wypadku obiektów przestrzennych, można sobie wyobrazić, że granice te są przesuwane, że coś się na nich dzieje, np.:

(21) Twoja twórczość sytuuje się na granicy między poezją wybitną a podrzędną.

Tak więc w języku rodzaj rozgraniczanych obiektów nie jest relewantny (inaczej niż sugerują to definicje słownikowe).

W świetle przedstawionych analiz proponuję wyróżnić dwie jednostki języka oparte na segmencie granica: granice czegoś i granica między czymś a czymś. Obie granice w jakiś sposób ograniczają obiekt, a ich brak uniemożliwia jego lokalizację. Obie są bytami myślowymi, wyznaczonymi przez mówiącego, czasem w oparciu o tradycję bądź system wiedzy, zwłaszcza w wypadku granic państw i innych obiektów geograficznych.

Nadanie obiektowi granic pozwala na wyodrębnienie go (jako całości) z otoczenia, przy czym właściwości tego otoczenia są irrelewantne. Mówienie o jego granicach służy do lokalizacji obiektu w przestrzeni. Proponuję zatem następującą eksplikację:

${ }^{16} \mathrm{~W}$ pojęciu GRANICY zawiera się znaczenie zarówno filozoficznej Grenze, jak i Schranke. 


\section{granice czegośs}

'wiem, że poza czymś istnieje coś $_{\mathrm{j}}$ '

dlatego myślę o czymś, co je oddziela;

teraz wiem, gdzie jest coś,

gdzie: $\operatorname{coś}_{i}-$ obiekt, o którym mowa, $\cos _{j}-$ otoczenie tego obiektu.

Zważywszy na obecność dwóch obiektów (coś i coś $_{j}$ ) w eksplikacji, można by się zastanawiać, czy znaczenia jednostki granice czegoś nie da się sprowadzić do znaczenia granicy między czymś a czymś. Wydaje się jednak, że przeciw takiemu rozwiązaniu przemawiają co najmniej dwa argumenty. Po pierwsze, gdy mówię o granicach Układu Słonecznego, wyobrażam sobie Układ Słoneczny jako całość, mogę go zlokalizować w przestrzeni. Tymczasem w wypadku granicy polsko-niemieckiej nie mówię o Polsce (jako całości) i Niemczech (jako całości), ale o punkcie styku tych dwóch państw, co pokazują przekształcenia poniższych wypowiedzeń:

(22) Doszli do granicy polsko-rosyjskiej. $\neq$ Doszli do granicy Polski i granicy Rosji.

(23) Dostrzegłem granicę między dżunglą a woda. $\neq$ " Dostrzegłem granicę dżungli i granicę wody.

(24) Istnieje jednak granica między kiczem a tandeta. $\neq$ Istnieje granica kiczu i granica tandety.

Takie oddzielenie obu obiektów, jeśli w ogóle jest komunikacyjnie uzasadnione (por. [23]), skutkuje tym, że zanika informacja o tym, iż sasiadują one ze sobą (por. [24]). Dlatego też, i to po drugie, rezygnacja z uznania istnienia jednostki granice czegoś byłaby niezgodna $\mathrm{z}$ tradycją filozoficzną... i zdrowym rozsądkiem, gdyż „granica między” nie implikuje wyodrębniania przedmiotu z otoczenia, odnosi się tylko do wiedzy mówiącego, że istnieją dwa obiekty o różnych cechach, które w pewnym miejscu się stykają. W eksplikacji „granicy między” nie będę się zatem odwoływać do lokalizacji obiektu: 


\section{granica między czymśs a czymś}

'wiem, że coś $\mathrm{i}$ i coś $\mathrm{j}_{\mathrm{j}}$ są różne, dlatego myślę o czymś, co je oddziela;

teraz wiem, gdzie się kończy coś ${ }_{i}$ i gdzie się zaczyna coś,

gdzie: $\cos _{i}-$ pierwszy obiekt, $\cos _{j}-$ drugi obiekt.

Wyrażenia kończy i zaczyna są konwencjonalne - zakładam, że koniec czegoś $_{\mathrm{i}}$ sąsiaduje z początkiem czegoś, choć równie dobrze mogłoby być odwrotnie $^{17}$. Taka formuła oddaje, jak myślę, sens mówienia o ,granicy między", która nie służy do lokalizowania obiektów, ale do zdawania sprawy z tego, że przylegają one do siebie, tzn. że niczego między tymi obiektami nie $\mathrm{ma}^{18}$.

Tak więc, gdy mówię o granicach Układu Słonecznego, 'wiem, że poza Układem Słonecznym istnieje coś innego, dlatego myślę o czymś, co je oddziela; teraz wiem, gdzie jest Układ Słoneczny’. Mówiąc o granicy między niebem a ziemiq, 'wiem, że niebo i ziemia są różne, dlatego myślę o czymś, co je oddziela; teraz wiem, gdzie kończy się niebo i gdzie zaczyna się ziemia'.

\section{Bibliografia}

Aronow R., 1976, Ciągłość a dyskretność przestrzeni i czasu, w: Przestrzeń, czas, ruch, przeł. M. Korzeniowska, Warszawa: Państwowe Wydawnictwo Naukowe, s. 91-121.

Balle Ch., 1990, Tabus in der Sprache, Frankfurt am Main-Bern-New York-Paris: Wallstein-Verlag.

Bartmiński J., Niebrzegowska-Bartmińska S., Nycz R. (red.), 2004a, Punkt widzenia w jezzyku $i$ w kulturze, Lublin: Wydawnictwo UMCS.

17 Pojęcia takie jak GÓRA, DÓ£, PRZÓD, TYŁ są subiektywne, por. np. Przybylska 2002: 140-151. Dotyczy to także pojęć KOŃCA i POCZĄTKU, por. Kubicka 2008.

18 Mało prawdopodobne wydają się wyrażenia typu granica między marazmem, głupota a okrucieństwem czy granica między Polska, Słowacja a Ukraina (przestrzeń musiałaby mieć więcej wymiarów). W razie potrzeby jednak do wyrażenia granica może być dodany kolejny argument, przy czym konieczne będzie znowu arbitralne określenie początku/końca obiektu. 
Bartmiński J., Niebrzegowska-Bartmińska S., Nycz R. (red.), 2004b, Punkt widzenia w tekście $i$ w dyskursie, Lublin: Wydawnictwo UMCS.

BednareK A., 1989, Wykładniki leksykalne ekwiwalencji. Analiza semantyczna wyrażeń typu „czyli”, Toruń: TNT.

Berezowski L., 2001, Articles and Proper Names, Wrocław: Wydawnictwo Uniwersytetu Wrocławskiego.

CAckowski Z., 1989, Zasadnicze zagadnienia filozofii, Warszawa: Książka i Wiedza.

Cockiewicz W., 1992, Aspekt na tle systemu słowotwórczego polskiego czasownika i jego funkcyjne odpowiedniki w języku niemieckim, Kraków: nakładem UJ.

FIzyKA: Arystoteles, 1968, Fizyka, przełożył, wstępem i przypisami opatrzył K. Leśniak, Warszawa: PWN.

FuldA H.-F., 1974, Grenze, Schranke, w: J. Ritter (red.), Historisches Wörterbuch der Philosophie, Bd. 3: G-H, Basel-Stuttgart: Schwabe, szp. 875-877.

Hoffmeister J., 1955, Wörterbuch der philosophischen Begriffe, 2. Aufl., Hamburg: Meiner.

ISJP: Bańko M. (red.), 2000, Inny słownik języka polskiego, Warszawa: Wydawnictwo Naukowe PWN.

Julia D., 1992, Słownik filozofii, przeł. K. Jarosz, Katowice: Książnica.

Kleiber G., 2003, Semantyka prototypu. Kategorie i znaczenie leksykalne, przeł. B. Ligara, Kraków: Universitas.

Kleszczowa K., 2005, Przestrzeń semantyczna kategorii „zupełności”, w: M. Balowski, W. Chlebda (red.), Ogród nauk filologicznych. Księga jubileuszowa poświęcona Profesorowi Stanisławowi Kochmanowi, Opole: Wydawnictwo Uniwersytetu Opolskiego, s. 293-301.

Kochman S., 1975, Polsko-rosyjskie stosunki językowe od XVI do XVIII w. Stownictwo, Opole-Wrocław: OTPN, Zakład Narodowy im. Ossolińskich.

Kubicka E., 2008, Über den Begriff der Grenze, w: E. Graf, N. Thielemann, R. Zimny (red.), Beiträge der Europäischen Slavistischen Linguistik (PoLYSLAV), Bd. 11, München: Verlag Otto Sagner, S. 125-131 („Die Welt der Slaven”, Bd. 33).

Lyons J., 1984, Semantyka, t. I, przeł. A. Weinsberg, Warszawa: Państwowe Wydawnictwo Naukowe.

Łukowski P., 2006, Paradoksy, Łódź: Wydawnictwo UŁ.

Metafizyka: Arystoteles, 1984, Metafizyka, przełożył, wstępem, komentarzem i skorowidzem opatrzył K. Leśniak, Warszawa: PWN.

Przybylska R., 2002, Polisemia przyimków polskich w świetle semantyki kognitywnej, Kraków: Universitas.

Przybylska R., 2006, Schematy wyobrażeniowe a semantyka polskich prefiksów czasownikowych do-, od-, prze-, roz-, u-, Kraków: Universitas. 
SEBAŃ: Bańkowski A., 2000, Etymologiczny słownik języka polskiego, Warszawa: Wydawnictwo Naukowe PWN.

SEBor: Boryś W., 2005, Słownik etymologiczny języka polskiego, Kraków: Wydawnictwo Literackie.

SESŁ: Sławski F., 1952-1982, Słownik etymologiczny języka polskiego, Kraków: TMJP.

Simmel G., 1983, Soziologische Untersuchungen über die Formen der Vergesellschaftung, 6. Aufl., Berlin: Duncker \& Humblot.

SJPD: Doroszewski W. (red.), 1958-1969, Słownik języka polskiego, Warszawa: Państwowe Wydawnictwo „Wiedza Powszechna”, Państwowe Wydawnictwo Naukowe.

SPsŁ: Sławski F., 1974-2001, Słownik prasłowiański, Wrocław: Zakład Narodowy im. Ossolińskich.

SPXVI: Mayenowa M.R., Pepłowski F. (red.), 1966-, Słownik polszczyzny XVI wie$k u$, Wrocław-Warszawa: Zakład Narodowy im. Ossolińskich, PAN.

SSTP: Urbańczyk S. (red.), 1953-2002, Słownik staropolski, Wrocław-Kraków: Zakład Narodowy im. Ossolińskich, PAN.

SW: Karłowicz J., Kryński A., Niedźwiedzki W. (red.), 1900-1927, Słownik języka polskiego, Warszawa: nakładem prenumeratorów.

SWJP: Dunaj B. (red.), 1996, Słownik współczesnego języka polskiego, Warszawa: Wilga.

TEuBERT W., 2006, Korpuslinguistik, Hermeneutik und soziale Konstitution der Wirklichkeit, Linguistik online XXVIII/3, s. 41-60.

USJP: Dubisz S. (red.), 2003, Uniwersalny słownik języka polskiego, Warszawa: Wydawnictwo Naukowe PWN.

\section{The concept of the BOUNDARY - once more}

( s u m m a r y)

The concept of the BOUNDARY, relevant in the philosophy for designating objects, has the same function also in the language. The word granica, from grań, i.e. a conventional sign set for separating one territory from another, in the process of time started to design not only the names of territories but also abstract names of objects without inherent boundaries. The author proposes to distinguish two lexical units with the sequence granica: granice czegoś 'boundaries of something', and granica między czymś a czyms' 'boundary between ... and ...', both of which separate an object from its surroundings. Using the first one, the speaker localizes the objects in space, whereas using the second one he separates it from other objects. 
